Volume and Issues Obtainable at Center for Sustainability Research and Consultancy

Journal of Accounting and Finance in Emerging Economies

ISSN: 2519-0318\&ISSN (E):2518-8488

Volume 7: Issue 2 June 2021

ᄃSRC Journal homepage: www.publishing.globalcsrc.org/jafee

\title{
Mediating Role of Working Capital Management in the Relationship of Corporate Governance Measures and Firm Performance: Panel Study from Pakistan
}

Areeba Khan, Institute of Business, Management and Administrative Sciences, The Islamia University of Bahawalpur, Pakistan.

Rana Muhammad Shahid Yaqub, Institute of Business, Management and Administrative Sciences, The Islamia University of Bahawalpur, Pakistan.

*Awais Javeed, Department of Management Sciences, University of Gujrat, Pakistan.

*Corresponding author's email: awaisjaveed@uog.edu.pk

ARTICLE DETAILS

History

Revised format: Mar 2021

Available Online: Apr 2021

\section{Keywords}

Corporate Governance, Corporate Finance, Firm Performance

\section{JEL Classification}

G30, G38

\begin{abstract}
Purpose: Corporate governance and management of working capital are seen as two main fields of corporate finance. The purpose of the research study is to examine the interrelationships between corporate governance, working capital management and performance of the firm.

Design/Methodology/Approach: Sample consists of 140 non-financial firms listed on the Pakistan Stock Exchange from 2008 to 2015. Data has been analyzed by using structural equation model. Mediating effects of managing working capital have been tested by using the approach suggested by Preacher and Hayes (2008).

Findings: The findings revealed that current ratio partially mediates the effect of size of the board and CEO role duality. For the other relationship the study found that board size affects firm performance positively whereas CEO duality and audit committee independence have negative impact on profitability of firms. For the relationship of working capital management on firm Performance, the study identified substantial negative and positive impacts on firm performance of the cash conversion period and current ratio, respectively.
\end{abstract}

Implications/Originality/Value: The current study was based on least considered variables and the pioneer in testing the complex relationship through SEM-AMOS.

(C2021, The authors, under a Creative Commons AttributionNonCommercial 4.0

Recommended citation: Khan, A., Yaqub, R. M. S., \& Javeed, A. (2021). Mediating Role of Working Capital Management in the Relationship of Corporate Governance Measures and Firm Performance: Panel Study from Pakistan. Journal of Accounting and Finance in Emerging Economies, 7(2), 281-294. https://doi.org/10.26710/jafee.v7i2.1655

\section{Introduction}

Corporate governance refers to those measures that provide financing for companies to ensure that 
they receive acceptable returns on investment (Shleifer \& Vishny, 1997). It also means that the company owner's joint effort is to protect themselves from deportation from anyone who controls and manages the company. This confiscation can take the form of the sale of the assets, production, or securities of the company by management to another institution that owns it at a price below the market price. In other cases, expropriation can occur in the form of inefficient families hiring as key managers or overpaying executives. Overall, expropriation conduces the Agency's problem proposed by Jensen and Meckling (1976).

Root cause of the agency problem in the corporate sector is the separation between operational control and ownership, as the owners do not actively participate in running the business, and this division of control can encourage the agency problem. It pushes CEOs to redirect the organization's resources to their own needs, which are in fact the property of the shareholders. To reduce agency problems, owners implement various control mechanisms called agency costs. Agency cost is the sum of all costs that a business owner must bear aiming to transform the agent's behavior in the principal's favor. To reduce the issue of an agency, the principal applies various monitoring and control mechanisms which are referred to as the expense of an agency. In Pakistan, The business sector was governed under the Companies Act 1913 prior to the implementation of the Companies Ordinance, 1984. In 1949 the country's first stock exchange was established in Karachi, and later on the other two Lahore and Islamabad stock markets joined the system. These three exchanges took on the position of money and capital markets. But the merger of these three exchanges formed Pakistan Stock Exchange Limited in January, 2016. The Institute of Chartered Accountant of Pakistan introduced the pioneer document for the Corporate Governance Code in 1998. Subsequently, the Securities and Exchange Commission of Pakistan published a Code of Corporate Governance in 2002 (SECP).

The corporate sector in Pakistan is controlled by SECP and the State Bank of Pakistan (SBP). SECP administers the stock exchange and has jurisdiction over listed companies under Stock Exchange listing criteria. Pakistan's state bank regulates the finance and banking sector, guides banks, and has full authority to restructure and penalize non-confirming financial institutions. In March 2002, SECP made its first major effort to improve corporate governance practices in Pakistan by issuing corporate governance code which became pertinent to all pubic listed companies. This Corporate Governance Code were subsequently updated in 2012 and then amended in July, 2014. These revisions to the code demonstrate that corporate governance principles are complex and for efficient governance framework these code need to be consistently reviewed.

Management of working capital applies to the organization of existing assets and existing liabilities of the company. For many reasons current asset management is critical for any organization. For any manufacturing company the proportion of current assets is approximately half of its total assets. Excessive investment in current assets may result in under-standard returns on the capital invested. On the other hand, companies may face difficulties in keeping business operations smooth by carrying few current assets (Horne \& John M. Wachowicz, 2008). The firm's ultimate aim is the wealth maximization of the owner while it is also necessary to preserve an adequate degree of liquidity. For these purposes, working capital management needs careful consideration, as it directly impacts company profitability (Raheman \& Nasr, 2007).

Working capital needs are reduced when a company achieves optimal amounts of components of working capital. Optimum working capital helps the businesses to reduce working capital requirements that maximize their free cash flow. Poor governance practices may contribute to inefficient management of working capital. Good governance practices evaluate how management uses business practices and resources.Keynes (1936) suggested three reasons for holding cash on individuals. He classified certain motives as i) transactionii) speculative and iii) precautionary. 


\section{Literature Review}

Jensen and Meckling (1976) illustrated the topic of corporate governance by shedding a light on a dispute between owners and managers. They argued that managers should not have the full advantages of organizational operations, but are kept accountable for their actions. As a result, managers use corporate capital to achieve personal benefits instead of optimizing shareholders' wealth.

Ghazali (2010) found that none of the corporate governance variables are substantially correlated with company efficiency. Sharma (2016) also found evidence in his analysis that firm performance is unrelated to any of the corporate governance metrics. Malik and Makhdoom (2016) demonstrated a clear positive correlation between Governance and success of Fortune five hundred companies. Whereas, Saeed et al. (2016) claimed the independence of the size of the board have a direct negative effect on the success of the companies.

The executive board operates a vital a significant part in the performance of a company by conducting command and control functions. Lipton and Lorsch (1992) concluded that Smaller boards perform more efficiently than larger boards, as the risk that certain directors will free ride the efforts of other boards is high in larger boards. Yermack (1996) indicated that the rise in the size of the board had a negative effect on firm valuation. The more an organization is dependent on external resources, the larger the board it should have (Pfeffer and Slancik, 1978). Mak and Kusnadi (2005) investigated a sample of Singapore and Malaysian firms and concluded that in both countries, the board size has a major negative relation with a company valuation. O'Connel and Cramer (2010) have indicated a major negative association between board size and the performance. Muller-Kahle et al. (2014) collected financial data from the top 100 listed companies in the United States and United Kingdom and revealed that board size correlated positively with firm value in both countries. Gaur et al. (2015) revealed that having a large number of board members translates into superior corporate performance. Sheik and Wang (2013) also showed that the size of the board had a significant effect on the company's results using data from Pakistani firms.

Numerous studies have shown that external directors on board can play a critical role in managing management activities. of independent directors are appointed on behalf of the shareholders to supervise management (Baysinger and Butler, 1985). Impartial directors are considered more autonomous than inside directors, and can more easily evaluate success in management (Fama and Jensen, 1983). Bhagat and Black (2001) investigated whether board independence is correlated with American firm's performance, and found no evidence that firms with more external directors on board are doing better. Bonn et al. (2004) Mentioned a affirmative correlation with the involvement of external directors on board and performance of Australian firms. Jackling and Johl (2009) looked at the impact of the governance attributes on Indian firm's financial performance. Significant positive impact on the company's performance was recorded by a greater proportion of external directors on board. Yammeesri and Herath (2010) joined the debate as they investigated whether corporate board structure effects corporate value using data from Thai firms and concluded that independent directors are not an important determinant of enhanced value of the firm.

In general, the duality of CEO refers to a circumstance in which one person is named CEO and chairman of the board of directors. The views of the theorists of agencies and theorists of stewardship regarding duality are quite contrasting. Agency theorists suggest that separating the CEO and the chairman of the board has a positive effect on the CEO's monitoring and control, and that firms that divide the position do better than those that do not (Rechner and Dalton 1991).In comparison, stewardship theory believers argue that the dual position of CEO creates a unity of command that can help companies make quicker and better decisions that allow firms to perform better than those firms that break these two titles (Donaldson and Davis, 1991). Baliga et al. (1996) 
documented that there is insufficient evidence that duality status affects the firms' organizational and long-term efficiency. Brickley et al.(1997) concluded that this chair separation has budding costs along with potential benefits. Authors concluded that the Separation costs outweigh the benefits for most major US organizations. In the Chinese perspective, the results of Gill and Mathur's study (2010) revealed a positive correlation of CEO duality with firmvalue, while Dogan et al. (2013) published contradictory findings concluded that CEO duality adversely affects firm performance.

The audit committee has direct clout to provide full admittance to financial information and is responsible for assessing the quarterly and annual financial statements and discussing with the auditor any concern resulting from the audit (Saleh et al. 2007). Carcello and Neal (2003) analyzed the attributes of the audit committee and concluded that improved standard of financial reporting would benefit from more independent committee. Abbott et al. (2004) established that an independent audit committee, consisting of at least one financially qualified member, meets four epoch a year, has a substantial negative association with the frequency of restatements. Lin et al. (2006) found that the audit committee's size had a substantial negative effect on earnings restatement while committee independence had no significant impact on reported earnings. Yesser et al. (2011) suggested substantial positive effects on the company performance of listed companies in Pakistan from the audit committee.

Claessens and Djankov (1999) analyzed data from 706 Czech companies over a 6-year period and concluded that owners with large blocks of shares force management to take action that improves firm profitability. Jaafar and El-Shawa (2009) seek to evaluate block holders' impact on the corporate output of 103 Jordan-based firms. Study results showed that ownership concentration plays an important and positive part in deciding company success. In comparison, Mollah et al. (2012)'s analysis found a clear negative correlation between ownership concentration and the firms ' financial results. They disclosed that it is decentralized ownership that improves the firms' efficiency and helps reduce tensions between agencies. Although Demsetz and Villalonga (2001) stated that concentration of ownership does not play any significant role in predicting organizational efficiency.

Previous studies conducted in different countries found a substantial association of working capital management with the company's liquidity and profitability. Shin and Soenen (1998) reported that the value of the company's net trade period shareholder can be increased by shortening it. Lazaridis and Tryfonidis (2006) established that managers can improve their organizations' income by managing the cash conversion period correctly and maintaining their components at an optimum level. Deloof (2003) identified significant negative impact on the gross operating income of Belgian companies from the cash conversion period. He further noted that by reducing the account receivable collection period and combining the inventory period to a reasonable amount companies, shareholder equity can be enhanced. Moreover, less profitable businesses are taking longer to pay their bills. Berg (2016) identified the negative impact of all CCC components on profitability calculated in terms of asset return (ROA). Afza and Nazir (2008) analyzed Impact of policies relating to working capital on profitability and argued that companies that opt for aggressive investment in working capital often adopt aggressive policies to fund working capital. In addition, authors said ambitious investment and working capital finance policies produce negative returns.

\section{Hypothesis Development}

Preacher \& Hayes(2008) defines mediation as the process by which certain variables influence other variables through interfering variables (also called mediators). Mediation occurs when an explanatory variable indirectly affects response variable via at least one variable that intervenes. The study used previously published studies to develop a testable model (see, for example, Shin 
and Soenen, 1998; Mak \& Kusnadi, 2005; Lazaridis and Tryfonidis, 2006; Raheman and Nasr, 2007; Bhagat and Bolton, 2008; Ghazali, 2010; Yesser et al . ,2011; Gill and Shah, 2012; Sheik \& Wang , 2013; Sharma,2016). To test the mediating role of working capital management in the corporate governance and performance of the firm relationships, this research applies the framework of Preacher and Hayes (2014).

H1:Working Capital Management significantly mediates the association between corporate governance and firm performance.

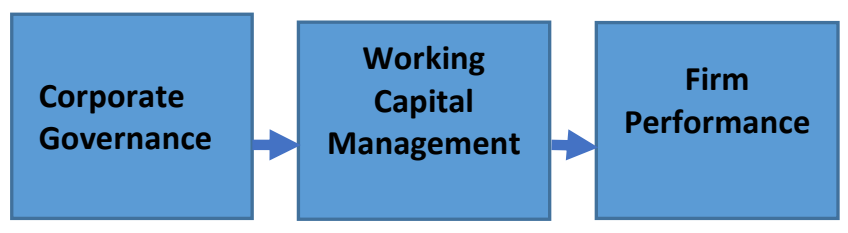

Figure 1: Research Model

\section{Research Methodology}

The study population covers all listed non-financial corporations in the Pakistan Stock Exchange (PSE). A total of 559 companies which belong to 35 different sectors are officially listed on PSE. Focusing on the goals of this study, the study excluded 132 financial companies covering seven sectors. The population for the study has therefore shrunk to 427 companies. Eight years (20082015) data was collected from the company's annual reports. The company's annual reports contain more detailed and reliable information than any other source of data (Fraser et al. 2006). The study used a balanced data panel matrix consisting of a time series (weekly, monthly, or annually) in the dataset for each cross-sectional member (individuals, firms, or countries) (Asteriou \&Hall, 2007). The data is examined using the Statistical Package for Social Science (SPSS) version 21 and Moment Structures Analysis (AMOS) version 21. The study used most famous way to test mediating effect that was presented by Baron and Kenny in 1986, where OLS regression or Structural Equation Model (SEM) is used to test mediating impact using a causal phase strategy. SEM also fairly controls the measurement error (Baron and Kenny, 1986).

This research employed non-probabilistic sampling technique explicitly purposive sampling to collect samples from non-financial firms. This technique allows a researcher to use his discretion in choosing those cases that will help him to answer research questions and attain his research goals (Saunders, 2011). At first, it is ensured that all the companies included in the survey remained listed throughout the study period chosen and that they were not delisted / acquired / merged or renamed. After this the process of data collection was started for the required variables. Companies with no official website were removed from sample collection, or those companies whose data was unavailable for the entire study period. After making the aforementioned adjustments, the study included sample of 140 companies.

\begin{tabular}{|c|c|c|}
\hline Total Listed Companies & & 559 \\
\hline Less: Commercial Banks & 23 & \\
\hline Less: Insurance Companies & 31 & \\
\hline Less: Investment Banks & 29 & \\
\hline Less: Leasing Companies & 11 & \\
\hline Less: Close End Mutual Funds & 8 & \\
\hline Less: Modarbah Companies & 29 & \\
\hline Less: Real Estate Investment Trust & 1 & \\
\hline
\end{tabular}


Total Non-Financial ListedCompanies

Table 1: Listed Companies at Pakistan Stock Exchange

Source: Pakistan Stock Exchange Website

\section{Variables of the Research}

The analysis includes variables for corporate governance (Board size, CEO duality, board independence, independence of the audit committee, ownership concentration), variables for working capital (current ratio and cash conversion Cycle), and performance variables (return on assets).

\begin{tabular}{|c|c|c|c|}
\hline \multirow{6}{*}{$\begin{array}{l}\text { Corporate } \\
\text { Governance }\end{array}$} & Variable Name & Symbol & Operational Definition \\
\hline & Board Size & $\mathrm{BS}$ & The total number of Board directors \\
\hline & Board Independence & BI & $\begin{array}{l}\text { The ratio of independent directors to total number of } \\
\text { directors. }\end{array}$ \\
\hline & CEO Duality & $\mathrm{CD}$ & $\begin{array}{l}\text { A dummy variable that takes the value of } 1 \text { if CEO also } \\
\text { serves as Board Chairman, otherwise } 0 .\end{array}$ \\
\hline & $\begin{array}{l}\text { Audit Committee } \\
\text { Independence }\end{array}$ & $\mathrm{ACI}$ & $\begin{array}{l}\text { Ratio of non-executive/independent directors to total number } \\
\text { of directors in audit committee. }\end{array}$ \\
\hline & $\begin{array}{l}\text { Ownership } \\
\text { Concentration }\end{array}$ & OWC & $\begin{array}{l}\text { Ratio of Common Shares held by five individual largest } \\
\text { shareholders to total number of outstanding shares. }\end{array}$ \\
\hline \multirow{2}{*}{$\begin{array}{l}\text { Working } \\
\text { Capital } \\
\text { Management }\end{array}$} & $\begin{array}{l}\text { Cash Conversion } \\
\text { Cycle }\end{array}$ & $\mathrm{CCC}$ & $\begin{array}{l}\text { It is determined as by adding inventory holding period and } \\
\text { average collection period and subtracting average payment } \\
\text { period }\end{array}$ \\
\hline & Current Ratio & CR & Ration calculated as (Current assets / Current liabilities) \\
\hline $\begin{array}{l}\text { Firm } \\
\text { Performance }\end{array}$ & Return on Assets & ROA & Ratio of net profit before tax to total assets \\
\hline
\end{tabular}

Table 2 Definition of the variables of the study

Source: Authors' Compilation

\section{Results and Discussion.}

Table 3 provides detailed statistics of all of the variables used in this analysis. 


\begin{tabular}{|l|c|c|c|c|c|c|c|c|c|}
\hline & Variable & Mean & $\begin{array}{c}\text { Standard } \\
\text { Deviation }\end{array}$ & Min & Max & Median & Kurtosis & Skewness & Obs. \\
\hline Panel A & ROA & 0.060 & 0.106 & -0.521 & 0.533 & 0.049 & 3.057 & 0.305 & 1120 \\
\hline \multirow{3}{*}{ Panel B } & BS & 8 & 1.415 & 6 & 15 & 7 & 6.280 & 2.238 & 1120 \\
\cline { 2 - 10 } & BI & 0.655 & 0.203 & 0 & 1 & 0.714 & 0.978 & -1.023 & 1120 \\
\cline { 2 - 10 } & CD & 0.204 & 0.403 & 0 & 1 & 0 & 0.154 & 1.467 & 1120 \\
\cline { 2 - 10 } & ACI & 0.853 & 0.204 & 0 & 1 & 1 & 3.129 & -1.529 & 1120 \\
\cline { 2 - 10 } & OWC & 0.625 & 0.183 & 0.031 & 0.971 & 0.645 & -0.613 & -0.249 & 1120 \\
\hline \multirow{2}{*}{ Panel C } & CCC & 43.95 & 116.48 & -726.5 & 1057.71 & 47.602 & 16.062 & 0.198 & 1120 \\
\cline { 2 - 10 } & CR & 1.494 & 1.482 & 0.0009 & 17.390 & 1.112 & 34.070 & 4.935 & 1120 \\
\hline
\end{tabular}

Table 3: Analysis

Source: Authors' Compilation

Panel A of the table shows descriptive figures for ROA of the sampled firms, the average return of $6.00 \%$ shows that most of the listed firms on the Pakistan Stock Exchange are earning profit.(Javeed et al. 2014; Sheik and Wang, 2013).Panel B of the table provides descriptive figures for the factors of corporate governance. For companies the average board size is 8 . It evokes the fact that Pakistani companies have roughly identical board sizes and lean to smaller boards. These findings provide some support to findings from (see, for example, Guo and KGA, 2012; Mashayekhi and Bazazb, 2008). The presence of independent directors on Pakistani boards is on average $65 \%$. This indicates companies in Pakistan are strongly independent from the board (Yesser, 2011; Harford et al., 2008). Statistics on CEO duality showed that 80 percent of firms have external chairman as chairman of the board, indicating that most companies in Pakistan have separate chairman and CEO. These results echo the findings of (Javeed et al.2014; Sheik and Wang, 2013). The degree of independence in board members of the audit committee has an average value of 85.3 percent and deviates from 20 percent, indicating high independence of audit committee members among firms in Pakistan. Lin et al. (2006) published similar figures for independence of the audit committee. The five largest shareholders hold a total of 62.5 per cent, which suggests a high concentration of ownership as reported (Sheik and Wang, 2012; Javeed et al., 2014). Panel C explains the descriptive figures for the factors in the management of working capital. The conversion period in cash is 43.95 days average. The average of 43.95 means that businesses listed on the Pakistan Stock Exchange will quickly turn inventory into revenue and receive cash owed by consumers, but will take a little longer to pay suppliers. The High deflection norm of 116.48 days is an indication of the widespread difference between the sampled firms in the cash conversion period. The 44-day CCC is similar to Deloof (2003) results. These results show that companies are classified as a moderate liquid in Pakistan.

Table 4 shows the Pearson correlation coefficient between the variables used in the sample with a meaning level of 0.10 or less. A strong correlation between variables may signal the multicollinearity problem (Saunders, 2011). The correlation coefficient above 0.9 indicates that multicollinearity could occur (Asteriou \&Hall, 2007). The correlation matrix does not imply any problem with multicollinearity as the values for the coefficient are well below the specified limit of 0.8 .

\begin{tabular}{ccccccccc}
\hline & BS & BI & CD & ACI & OWC & CR & CCC & ROA \\
\hline BS & 1 & $.142^{* * *}$ & $-.109^{* * *}$ & $0.135^{* * *}$ & $-.232^{* * *}$ & $.077^{* *}$ & $.092^{* * *}$ & $.117^{* * *}$ \\
\hline
\end{tabular}




\begin{tabular}{lccccccc}
\hline BI & 1 & $-.174 * * *$ & $0.605 * * *$ & .020 & -.002 & -.011 & .013 \\
CD & & 1 & $-0.149 * * *$ & -.008 & $-.152 * * *$ & -.051 & $-.230 * * *$ \\
ACI & & & 1 & .050 & .022 & -.014 & -.009 \\
OWC & & & 1 & $.087 * * *$ & $-.097 * * *$ & .035 \\
CR & & & & 1 & $.138 * * *$ & $.320 * * *$ \\
CCC & & & & & 1 & .005 \\
ROA & & & & & & \\
\hline
\end{tabular}

$*, * *, * * *$ denotes significance at the level of $10 \%, 5 \%$ and $1 \%$ respectively.

Table 4: Correlation Table

Source: Authors' Compilation

\begin{tabular}{ccccc}
\hline & & & $\begin{array}{c}\text { Estimate } \\
\text { Standardized }\end{array}$ & P-Value \\
\hline ROA & $<--$ & BS & .093 & .001 \\
ROA & $<--$ & BI & .003 & .927 \\
ROA & $<---$ & CD & -.186 & .000 \\
ROA & $<---$ & ACI & -.060 & .085 \\
ROA & $<---$ & OWC & .028 & .331 \\
\hline
\end{tabular}

Table 5: Impact of Corporate Governance Measures on Firm Performance Source: Authors' Compilation

The results of the corporate governance regression on performance of the firm are shown in Table 5. Individually, board size shows substantial positive relationship with firm performance.In contrast, the duality of the CEO role and the independence of the audit committee are significantly and related negatively to ROA at the level of 1 per cent and 10 per cent respectively. In addition, the size of the board and CEO duality presents a significant relationship at the significance level of $1 \%(\mathrm{P}<0.01)$. With regard to variables in corporate governance, ROA is significant and directly correlated with the size of the board, indicating that larger boards increase profitability.However, significantly negative is the relationship between ROA and CEO duality, which shows the dual role of CEO leads to a reduction in profitability.

\begin{tabular}{ccccc}
\hline & & & $\begin{array}{c}\text { Standardized } \\
\text { Estimate }\end{array}$ & P-Value \\
\hline ROA & $<--$ & CCC & -.051 & .065 \\
ROA & $<---$ & CR & .290 & .000 \\
\hline
\end{tabular}

Table 6: Effect of Working Capital Management on Performance of the Firm Source: Authors' Compilation

The table above shows that cash conversion cycle coefficient showing a generalizable relationship with ROA at a meaning level of 10 per cent. The table also highlighted that at 1 percent level of significance the current ratio has a highly positive relationship with ROA. 


\begin{tabular}{lcccc}
\hline & & & $\begin{array}{c}\text { Standardized } \\
\text { Estimate }\end{array}$ & P-Value \\
\hline $\mathrm{CCC}$ & $<---$ & BS & .073 & .019 \\
$\mathrm{CCC}$ & $<---$ & $\mathrm{BI}$ & -.018 & .627 \\
$\mathrm{CCC}$ & $<---$ & $\mathrm{CD}$ & -.049 & .103 \\
$\mathrm{CCC}$ & $<---$ & ACI & -.016 & .660 \\
$\mathrm{CCC}$ & $<---$ & OWC & -.079 & .009 \\
\hline
\end{tabular}

Table 7: The Impact of Corporate Governance on Working Capital Management Source: Authors' Compilation

Board size shows a generalizable at 5 percent level relationship with CCC. This means that the increase in board members will prolong the company's cash conversion cycle. Ownership concentration is negatively significant at 1 percent significance level and is significantly correlated with the cash conversion period. That suggests block holders tend to shorten the cycle of cash conversion.

\begin{tabular}{ccccc}
\hline & & & $\begin{array}{c}\text { Standardized } \\
\text { Estimate }\end{array}$ & P-Value \\
\hline $\mathrm{CR}$ & $<--$ & $\mathrm{BS}$ & .091 & .003 \\
$\mathrm{CR}$ & $<---$ & $\mathrm{BI}$ & -.051 & .166 \\
$\mathrm{CR}$ & $<---$ & $\mathrm{CD}$ & -.148 & .000 \\
$\mathrm{CR}$ & $<---$ & $\mathrm{ACI}$ & .014 & .707 \\
$\mathrm{CR}$ & $<---$ & OWC & .107 & .000 \\
\hline
\end{tabular}

Table 8: The Impact of Corporate Governance on Current Ratio Source: Authors' Compilation

Current ratio acted as stated variable in the table above, and variables of governance as explanatory variables. Board scale, CEO duality and concentration of ownership all three demonstrate generalizable relationships at a level of 1 per cent significance. It means that increased board size and block holder owners play a significant role in increasing current ratio while negative CEO duality coefficient showing that CEO duality presence reduces current ratio. On the other hand, the other explanatory variables of independence of the board, independence of the audit committee, do not indicate generalizable ties. 


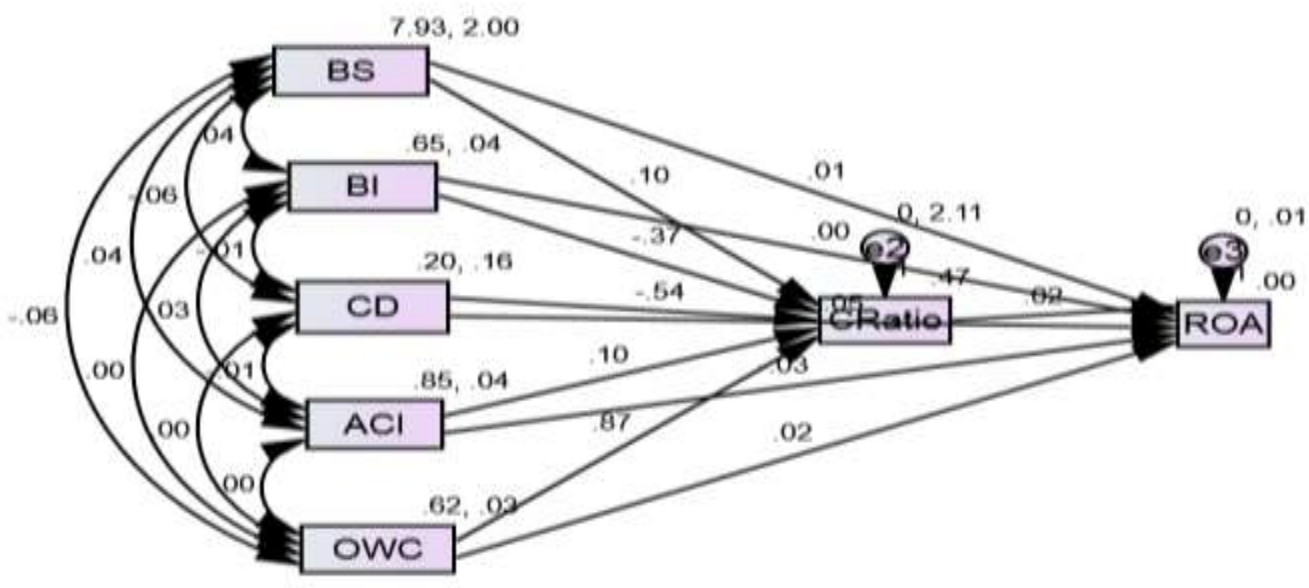

Figure 2: Mediation of Current Ratio in Corporate Governance and Firm Performance Relationship Source: Authors' Compilation

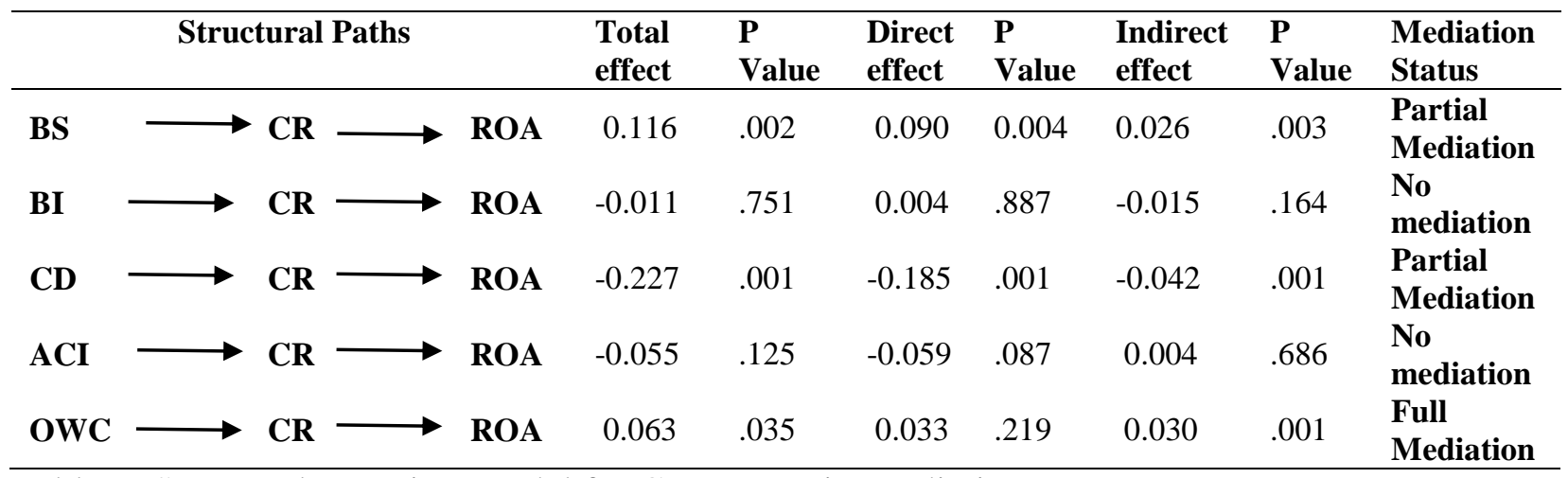

Table: 9 Structural Equation Model for Current Ratio Mediation Source: Authors' Compilation

The results for the mediating effect of the current ratio are given in table 9. According to Preacher \& Hayes (2008), the existence of mediation is proved by a substantial P-value for indirect influence. In the above below, Board size direct as well as indirect effects are significant. If both direct and indirect effects are important, this implies partial mediation, indicating that some of the direct effect of board size has been absorbed by the current ratio and that effect is transmitted to ROA from the current ratio. The duality of CEOs exhibiting partial mediation is also important in both direct and indirect results. Direct effect is negligible for ownership concentration, while indirect effect is important, indicating that the current ratio completely mediates the ownership concentration and ROA relationship. 


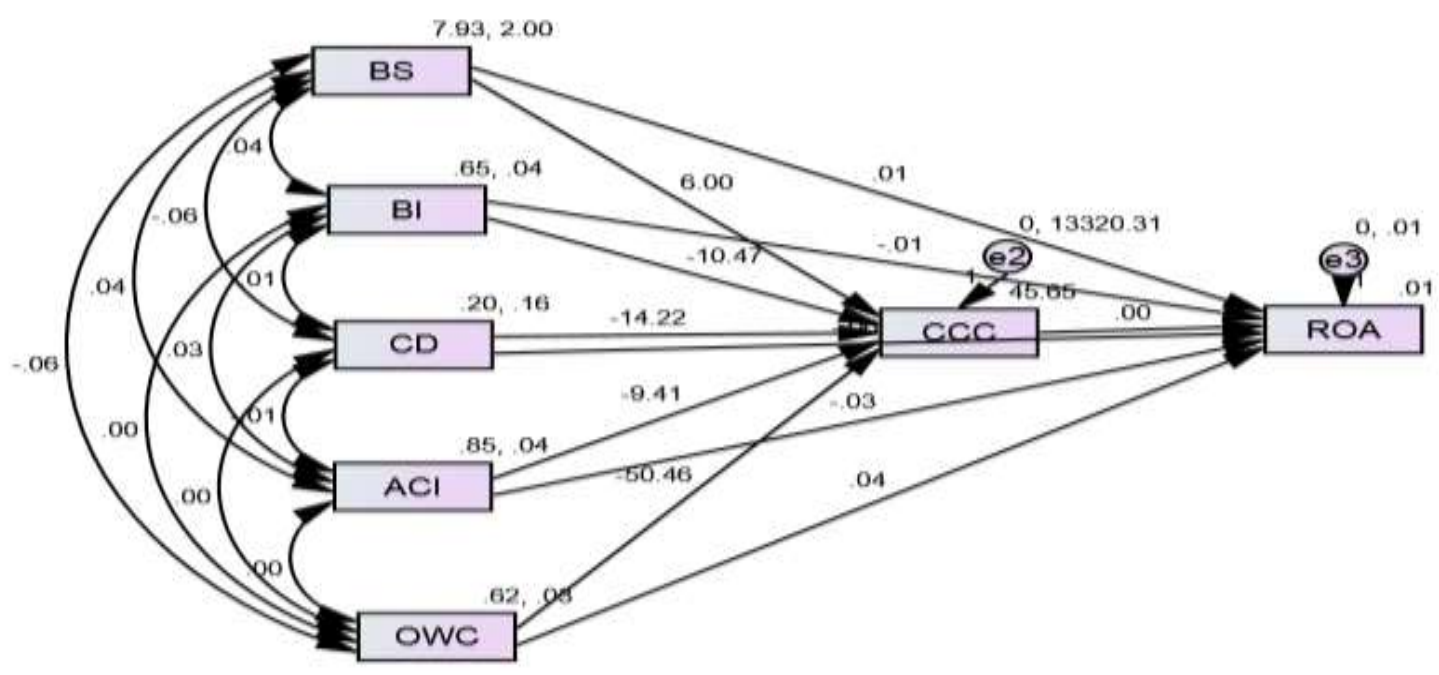

Figure 3: Mediation of Cash Conversion Cycle Ratio in Corporate Governance and Firm Performance Relationship

Source: Authors' Compilation

\begin{tabular}{|c|c|c|c|c|c|c|c|c|}
\hline & Structural Paths & $\begin{array}{l}\text { Total } \\
\text { effect }\end{array}$ & $\begin{array}{l}\text { P- } \\
\text { Value }\end{array}$ & $\begin{array}{l}\text { Direct } \\
\text { effect }\end{array}$ & $\begin{array}{l}\text { P- } \\
\text { Value }\end{array}$ & $\begin{array}{l}\text { Indirect } \\
\text { effect }\end{array}$ & $\begin{array}{l}\text { P- } \\
\text { Value }\end{array}$ & $\begin{array}{l}\text { Mediation } \\
\text { Status }\end{array}$ \\
\hline BS & ROA & 0.116 & 0.016 & 0.117 & 0.013 & -0.001 & 0.566 & $\begin{array}{l}\text { No } \\
\text { Mediation }\end{array}$ \\
\hline BI & ROA & $\overline{0} .011$ & 0.728 & -0.011 & 0.750 & 0.000 & 0.437 & $\begin{array}{l}\text { No } \\
\text { mediation }\end{array}$ \\
\hline CD & ROA & 0.227 & 0.007 & -0.227 & 0.000 & 0.001 & 0.533 & $\begin{array}{l}\text { No } \\
\text { Mediation }\end{array}$ \\
\hline ACI & ROA & $\overline{-}-055$ & 0.183 & -0.055 & 0.182 & 0.000 & 0.652 & $\begin{array}{l}\text { No } \\
\text { mediation }\end{array}$ \\
\hline OWC & $\rightarrow \mathrm{CCC}$ & 0.063 & 0.032 & 0.062 & 0.033 & 0.001 & 0.658 & $\begin{array}{l}\text { No } \\
\text { Mediation }\end{array}$ \\
\hline
\end{tabular}

Table: 10 Structural Equation Model for Cash Conversion Cycle Mediation

Source: Authors' Compilation

From the indirect impact portion of the above table it can be shown that when CCC plays mediating function, none of the corporate governance variables show significance. It proposed that Cash Conversion Period does not mediate the corporate governance relationship and the variables of firm results.

\section{Regression Analysis: Mediating Role of Working Capital Management}

The study is aimed at analyzing the mediating role of working capital management In the corporate governance and organizational efficiency. CCC role as mediator was tested using Structural Equation Model. Results revealed that the CCC does not mediate the relationship as the indirect effects of all variables in corporate governance on ROA showing insignificant results (Pvalues $>0.05$ ). After CCC, the mediating role of the second variable in the management of working capital i.e. Current Ratio was also tested using the Structural Model Equation. Results reported that the current ratio plays the mediating role in the corporate governance and corporate performance relationship. Board size, duality of CEO and concentration of ownership showing significant indirect effects whilst independence of board and audit committee showing no significant indirect 
effects. Current ratio partially mediates the Relationship between the composition of the board and business results as both the direct and indirect effects indicate partial mediation is significant. In other words, board size increase allows the current ratio to rise, and this rise in the current ratio eventually contributes to increased profitability. Significant is the direct and indirect impact of CEO duality on ROA, indicating that the current ratio partially mediates the bonding of CEO duality on ROA. Furthermore, the negative coefficient indicates that CEO duality has a detrimental impact on the current ratio, which decreases firm efficiency.

On the other hand, the current ratio fully mediates the concentration of ownership and firm results relationship, since the direct effect is insignificant whereas the indirect effect is significant. It means that there is no direct interaction between concentration of ownership and ROA, but when the current ratio is inserted in the interaction as a mediator, the indirect effect becomes important, implying that block holder owners induce management to take certain actions that in turn increase the company's efficiency.

\section{Conclusion}

This study is undertaken to accomplish several goals. On the one hand, it analyzed the corporate governance and working capital management association on corporate results and on the other hand, it evaluated the mediating role of working capital management in the aforementioned relationship using secondary data from Pakistan. Findings show important positive relationship between board size and results. These findings are well aligned with the beliefs of resourcedependence theorists who claim to make it easier for firms to access external resources by getting more members in boards and allow firms to develop faster.Findings also showed significant negative influence of CEO duality on ROA. Agency theories also assume that one person performing both roles may adversely affect the performance of a company. The study failed to recognize any major effect on corporate performance from board independence and ownership concentration. These findings suggest that any improvement in those variables does not contribute significantly to the success of the listed business. It can be argued that variables in corporate governance have a significant effect on private-sector success in Pakistan. The present study documents negative association of $\mathrm{CCC}$ with ROA in achieving the other goal, which implies that degree of swiftness in purchasing raw material and collecting credit sales receivables positively affects profitability. In addition, the positive effect of the current ratio on ROA highlights the fact that cash enriched companies will take advantage of short lived opportunities. Finally, the research examined the mediating impact of corporate governance and firm performance relationships in the management of working capital. Results reported that the current ratio partially mediates the association between board size and CEO duality while the association between ownership concentration and firm output is completely mediated (direct effect is negligible while indirect effect is significant) while the cash conversion period has shown no mediating impact in the relationship of interest.

\section{References}

Abbott, Lawrence J., Susan Parker, and Gary F. Peters. "Audit committee characteristics and restatements." Auditing: A Journal of Practice \& Theory 23.1 (2004)

Afza, T., \& Nazir, M. S. (2008). Working capital approaches and firm's returns. Pakistan Journal of Commerce and Social Sciences, 1(1), 25-36.

Baliga, B. R., Moyer, R. C., \& Rao, R. S. (1996). CEO duality and firm performance: What's the fuss?. Strategic Management Journal, 41-53.

Baysinger, B. D., \& Butler, H. N. (1985). Corporate governance and the board of directors: Performance effects of changes in board composition. Journal of Law, Economics, \& Organization, 1(1), 101-124. 
Bhagat, S., \& Bolton, B. (2008). Corporate governance and firm performance. Journal of Corporate Finance, 14, 257-273.

Bonn, I., Yoshikawa, T., \& Phan, P. H. (2004). Effects of Board Structure on Firm Performance: A Comparison Between Japan and Australia. Asian Business \& Management, 3, 102-125.

Brickley, J. A., Coles, J. L., \& Jarrell, G. (1997). Leadership structure: Separating the CEO and Chairman of the Board. Journal of Corporate Finance, 3, 189-220.

Carcello, J. V., \& Neal, T. L. (2003). Audit Committie independence. The Accounting Review, 78(1), 95-117.

Claessens, S., \& Djankov, S. (1999). Ownership Concentration and Corporate Performance in the Czech Republic. Journal of Comparative Economics, 27, 498-513.

Deloof, M. (2003). Does working capital management affect profitability of Belgian firms?. Journal of business finance \& Accounting, 30(3-4), 573-588.

Demsetz, H., \& Villalonga, B. (2001). Ownership structure and corporate performance. Journal of Corporate Finance, 7, 209-233.

Donaldson, L., \& Davis, J. H. (1991). Stewardship theory or agency theory: CEO governance and shareholder returns. Australian Journal of management, 16(1), 49-64.

Gaur, S. S., Bathula, H., \& Singh, D. (2015). Ownership concentration, board characteristics and firm performance A contingency framework. Management Decision, Vol. 53 No. 5, 911931.

Ghazali, N. A. (2010). Ownership structure, corporate governance and corporate performance in Malaysia. International Journal of Commerce and Management, Vol. 20 No. 2, 109-119.

Gill, A., \& Shah, C. (2012). Determinants of corporate cash holdings: Evidence from Canada. International Journal of Economics and Finance, 4(1), 70.

Gill, A., Biger, N., \& Mathur, N. (2010). The relationship between working capital management and profitability: Evidence from the United States. Business and economics journal, 10(1), $1-9$.

Guo, Z., \& KGA, U. K. (2012). Corporate Governance and Firm Performance of Listed Firms in Sri Lanka. Procedia - Social and Behavioral Sciences, 40, 664-667.

Fama, E. F., \& Jensen, M. C. (1983). Separation of ownership and control. The journal of law and Economics, 26(2), 301-325.

Harford, J., Mansi, S. A., \& Maxwell, W. F. (2008). Corporate Governance and Firm Cash Holdings in the U.S. Journal of Financial Economics, 87, 535-555.

Horne, J. C., \& John M. Wachowicz, J. (2008). Fundamentals of Financial Management (Edition 13).

Jaafar, A., \& El-Shawa, M. (2009). Ownership concentration, board characteristics and performance: evidence from Jordan. In Accounting in Emerging Economies (pp. 73-95). Emerald Group Publishing Limited.

Jackling, B., \& Johl, S. (2009). Board Structure and Firm Performance: Evidence from India's Top Companies. Corporate Governance: An International Review, 17(4), 492-509.

Javeed, A., Hassan, M., \& Azeem, M. (2014). Interrelationship among Capital Structure, Corporate Governance Measures and Firm Value: Panel Study from Pakistan. Pakistan Journal of Commerce and Social Sciences, 8(3), 572-589.

Jensen, M. C., \& Meckling, W. H. (1976). Theory of the firm: Managerial behavior, agency costs and ownership structure. Journal of financial economics, 3(4), 305-360.

Keynes, J. M. (1936). The General Theory of Employment, Interest, and Money . Harcourt Brace Jovanovich, 170-174.

Lazaridis, I., \& Tryfonidis, D. (2006). Relationship between working capital management and profitability of listed companies in the Athens stock exchange. Journal of Financial Management and Analysis, 19(1), 25-26.

Lin, J. W., Li, J. F., \& Yang, J. S. (2006). The effect of audit committee performance on earnings quality. Managerial Auditing Journal, 21(9), 921-933. 
Lipton, M., \& Lorsch, J. W. (1992). A Modest Proposal for Improved Corporate Governance. The Business Lawyer, 48(1), 59-77.

Mak, Y., \& Kusnadi, Y. (2005). Size Really matters: Further evidence on the relationship between board size and firm value. Pacific-Basin Finance Journal, 13, 301-318.

Malik, M. S., \& Makhdoom, D. D. (2016). Does corporate governance beget firm performance in fortune global 500 companies? Corporate Governance: The International Journal of Business in Society, 16(4).

Mashayekhi, B., \& Bazaz, M. S. (2008). Corporate Governance and Firm Performance in Iran. Journal of Contemporary Accounting \& Economics, 4(2), 156-172.

Mollah, S., Farooque, O. A., \& Karim, W. (2012). Ownership structure, corporate governance and firm performance Evidence from an African emerging market. Studies in Economics and Finance, Vol. 29 No. 4, 301-319.

Muller-Kahle, M., Wang, L., \& Wu, J. (2014). M.I. Muller-Kahle Liu Wang Jun Wu. Managerial Finance, Vol. 40 No. 7, 681-699.

O'Connel, V., \& Cramer, N. (2010). The relationship between firm performance and board characteristics in Ireland. European Management Journal, 28, 387-399.

Pfeffer, J., \& Salancik, G. R. (1978). The external control of organizations: A resource dependence perspective. New York: Harper \& Row,(6th ed.)

Raheman, A., \& Nasr, M. (2007). Working Capital Management And Profitability - Case Of Pakistani Firms. International Review of Business Research Papers, 3(1), 279-300.

Rechner, P. L., \& Dalton, D. R. (1991). CEO duality and organizational performance: A longitudinal analysis. Strategic Management Journal, 12(2), 155-160.

Saleh, N. M., Iskandar, T. M., \& Rahmat, M. M. (2007). Audit committee characteristics and earnings management: evidence from Malaysia. Asian Review of Accounting, Vol.15 No.2, 147-163.

Sharma, A. A. (2016). Corporate Governance and Firm Performance in Developing Countries: Evidence from India. The International Journal of Business in Society, 16.

Sheikh, N. A., \& Wang, Z. (2013). The impact of internal attributes of corporate governance on firm performance Evidence from Pakistan. International Journal of Commerce and Management, Vol. 23 No. 1, 38-55 .

Shin, H.-H., \& Soenen, L. (1998). Efficiency of Working Capital Management and Corporate Profitability. Financial Practice \& Education, 8(2).

Shleifer, A., \& Vishny, R. W. (1997). A Survey of Corporate Governance. The Journal of finance, $\operatorname{LII}(2)$.

Yammeesri, J., \& Herath, S. K. (2010). Board characteristics and corporate value: evidence from Thailand. Corporate Governance, VOL. 10 NO. 3 , 279-292.

Yermack, D. (1996). Higher market valuation of companies with a small board of directors. Journal of Financial Economics, 40, 185-211.

Yesser, Q. R., Entebang, H., \& Mansor, S. A. (2011). Corporate governance and firm performance in Pakistan: The case of Karachi Stock Exchange (KSE)-30. Journal of Economics and International Finance, 3(8), 482-491. 